\title{
The Social Status of /h/ in English
}

\author{
Ignacio Murillo López \\ University of Salamanca \\ ignatiusml@yahoo.com
}

\begin{abstract}
Languages are used as a vehicle of communication in the societies where each of them is spoken. Within those societies there are normally different groups, and each of those groups usually has a particular, or particular ways of communicating and using the language shared by all of them. Differences like this may be of several types: regional uses, a specific lexis depending on each one's occupation, formal or colloquial uses, social class variation, etc.

In this article the issue of social class language variation is explored. Particularly, our focus here is that of the status of the /h/-phoneme in English. Its pronunciation as a voiceless glottal fricative consonant or its absence is a symbol of the social divide in some places where English is spoken. In those places, the absence of the $/ \mathrm{h} /$-phoneme is considered erroneous, and the speech of those who do not use it, is not considered correct or appropriate.

Here we analyse the origin of that linguistic phenomenon, as well as the reasons for the establishment of the absence of the $/ \mathrm{h} /$-phoneme as a symbol of the social divide in some English-speaking territories.
\end{abstract}

Social divide into different classes not only has a repercussion from the sociological point of view, but also from the linguistic point of view, as Sociolinguistics has shown.

In English, as in the rest of the languages in the world, there are certain linguistic features which have become symbols of some particular social groups, either the upper, the middle, or the lower class. These features, which have become symbols of a particular social stratum, are technically called shibboleths.

According to The Oxford English Reference Dictionary, 'shibboleth' means, "a custom, doctrine, phrase, etc. distinguishing a particular class or group of people” (1996: 1336). 
It is widely known and accepted that language changes, not only from the regional or stylistic point of view, but also from the sociological one. It is in this context that we have to see the concept of shibboleth.

$/ h /$-dropping, a dialectal feature associated to the phonetic realisation of letter $<\mathrm{h}>$, is probably one of the most powerful shibboleths in English. So-called /h/-dropping is basically the absence of the $/ \mathrm{h} /$-phoneme -aspiration- in certain phonetic environments, especially at the beginning of a word. ${ }^{1}$ According to this, a word like happy would sound [æpi] rather than /'hæpi/.

This phenomenon, which is typical of many dialects of England, especially of those of London and the South East, is not restricted, nevertheless, to this particular realisation, as there are some other linguistic characteristics that would also fall under the umbrella term of /h/-dropping, as the Glide Cluster Reduction and the loss of the historical $/ \mathrm{h} /$ in medial positions. However, neither of the last two linguistic characteristics has the same sociolinguistic repercussion as the former.

Glide Cluster Reduction is the zero-realisation of $/ \mathrm{h} / \mathrm{in}$ certain groups such as $/ \mathrm{hw} / \mathrm{and}$ $/ \mathrm{hj} /{ }^{2}{ }^{2}<\mathrm{Hw}>$ and $<\mathrm{hj}>$ were historically pronounced $/ \mathrm{hw} / \mathrm{and} / \mathrm{hj} /$, but in some dialects they eventually became [w] and sometimes [j]. Therefore, words like where began to be pronounced [weər] or [weə] rather than [hweər] or [hweə].

The glide cluster / $\mathrm{hw} /$ was part of the Old English phonemic inventory. Evidence for this can be found by simply having a look at different texts in Old English, whose $<$ hw $>$ spelling is supposed to have been phonetic.

The Old English version of Ælfric's Latin A Colloquy on the Occupations says:

Hwelcne cræft canst pu?

Ic eom fiscere.

$H w æ t$ begietst pu of pinum cræfte?

Bileofan ic me begiete, and scrud, and feoh.

$\mathrm{Hu}$ gefehst pu pa fiscas?

Ic ga on minne bat, and rowe ut on pa ea, and weorpe min nett on pa ea.

$H w$ ilum ic weorpe angel ut mid æse, oppe spyrtan; and swa $h w æ t$ swa hie gehæftap ic nime.

$H w æ t$ dest pu gif hit unclæne fiscas beop?

Ic weorpe pa unclænan ut, and nime pa clænan me to mete.

$H w æ r$ ciepst pu pine fiscas?

On pære ceastre.

Hwa bygp hie?

Pa ceasterware. Ne mæg ic hira swa fela gefon swa ic sellan mæge.

$H w e l c e$ fiscas gefehst pu?

Ælas, and hacodas, and sceotan, and ealle opre fiscas pe on pæm eam swimmap.

For $h w \mathrm{y}$ ne fiscast pu on sæ?

$H w$ ilum ic do swa, ac seldom; for pæm hit is me micel rewett to pære sæ.

$H w æ t$ gefehst bu on pære sæ?

Hæringas, and leaxas, and styrian, and loppestran, and crabban, and fela operra fisca. ${ }^{\mathrm{i}}$

(in Mitchell and Robinson, 1992: 185) 
This text certainly provides evidence for words like hwat, hwilum, hwar, hwa, hwelce, or $h w y$, which had of course a [hw]-pronunciation for the $<\mathrm{hw}>$-spelling.

The Glide Cluster Reduction is believed to have taken place in the South of England as well as in the South East Midlands around the $12^{\text {th }}$ century, although it remained vulgar until the $18^{\text {th }}$ century. From that time onwards it gained more acceptance. Today this Glide Cluster Reduction is considered standard in many English-speaking territories. However, the [hw]-pronunciation still remains in certain dialects of English. As J.C. Wells says, "Glide Cluster Reduction characterizes most accents of England and Wales, the Southern hemisphere, and the West Indies, and also some American speech, but not the accents of Scotland and Ireland. The only local accents in England which retain [hw] are those of Northumberland and nearby" (1982: 228). This Glide Cluster Reduction process was actually the one shown below in the historical development of Old English hwar "where":

Hwær: $[\mathrm{hwær}]>[\mathrm{wær}]>[\mathrm{wer}]>[\mathrm{weər}]>[\mathrm{weə}]$.

South of England and South East Midlands.

Glide Cluster Reduction took place from the $12^{\text {th }}$ century onwards, although it remained vulgar until the $18^{\text {th }}$ century.

$=[$ hwær $]>[$ hw3r $]>[$ hweər $]>[$ hweə] .

North of England.

No Glide Cluster Reduction.

$=[\mathrm{hwær}]>>[\mathrm{hw} 3 \mathrm{r}]>[\mathrm{hweər}]$.

Ireland and some dialects of the United States.

No Glide Cluster Reduction.

After this Glide Cluster Reduction another phonetic development concerning / $\mathrm{h} /$ took place in English. It was the loss of the pronunciation of medial $<\mathrm{h}>$ in words like daughter or right. This is not exactly a case of $/ \mathrm{h} /$-dropping, as this medial $<\mathrm{h}>$ was pronounced either [X], as in the first example above, or [ç], as in the second, and not [h]. However, it is related to that phenomenon in a sense, as [X] and [C] were, together with [h], the three allophones of $/ \mathrm{h} /$ in Old and Middle English. ${ }^{3}$ The Old English word for daughter was dohtor, which was pronounced ['doxtər]. The development of this word gave ['doxtər] and then ['doxtər], ['dotər], ['do:tər], and ['do:tər( $\sim)$, where the original allophone of $/ \mathrm{h} /$, that is to say $[\mathrm{X}]$ - which became $[\mathrm{x}]$ later on- has certainly been lost. However it was there in Old English and it is still there in another Germanic language: German. In this language the sentence Ich habe deine Tochter gesehen "I have seen your daughter", is pronounced /iç 'ha:bə 'daInə 'toxtər gə'ze:ən/, where we can clearly see that the velar fricative / $\mathrm{x} /$ has been preserved. With the evidence provided by this, and regarding the phonetic development studied here, we could say that German has undergone less changes than English, where, at least, there seems to be a certain tendency to lose the sounds represented by the letter $\langle\mathrm{h}\rangle$.

An example of the loss of the [ç]-allophone -the other realisation of Old and Middle 
English medial /h/- is that of the word riht "right", which was originally pronounced [rIçt] and whose development gave [raiçt], [raIxt], and [raIt].

This medial $<\mathrm{h}>$ deletion took place during the $16^{\text {th }}$ and $17^{\text {th }}$ centuries, and is nowadays general in English, except for some traditional dialects of the North of England and Scotland. Hence, in Scots the phrase bright moonlight night is pronounced [brixt 'munlixt nIxt] rather than /braIt 'mu:nlaIt naIt/.

These two linguistic features are of course quite important in this / $\mathrm{h} /$-dropping process, but, as we said above, neither of them has the same sociolinguistic impact as non-standard initial/h/-dropping. 4

Non-standard initial /h/-dropping is what is normally meant by the term /h/-dropping, ${ }^{5}$ and, as J.C. Wells says, "H Dropping does appear to be the single most powerful pronunciation shibboleth in England. A London school teacher tells me he has only to look sternly at any child who drops an $/ \mathrm{h} /$, and that child will say the word again, this time correctly" (1982: 254). Also he says: "The correlation between H Dropping and social factors has been confirmed by sociolinguistic research. Among London schoolchildren, Hudson \& Holloway (1977) found that middle-class boys dropped only 14 percent of possible /h/s, while working-class boys dropped 81 percent" (1982: 254). This /h/dropping is typical of the popular dialects of London -especially of Cockney- and other areas in the rest of England and Wales. It is also common in Australia, New Zealand, and some of the English-speaking West Indies.

/h/-dropping is highly stigmatised and, because of that, educated people normally tend to avoid it. Therefore it is more usually found in people with less educated backgrounds. This means that for most people /h/-dropping is associated with lower-class speech and especially with that of London working-class. However this does not really mean that $/ \mathrm{h} /-$ dropping is restricted to lower-class speech. That is by no means the case. This dialectal feature also appears in some other social strata. However, the association of this phonetic characteristic with working-class speech in the mind of many people leads, and has led in the past, to self- and hypercorrection among other social groups. This is very important from the sociolinguistic point of view, as it means the stigmatisation of a mere dialectal development, and, therefore, the rise of a shibboleth, due to the association of a linguistic feature with a particular social group: in this case, the working-class in general or workingclass Londoners in particular.

The treatment of $\langle\mathrm{h}\rangle$ as [h] or as a zero-realisation has always been variable in different languages as $[\mathrm{h}]$ is just a mere aspiration which may eventually disappear. Initial aspiration used to be the current realisation of initial $\langle\mathrm{h}\rangle$ in Old English. However the confusion between [h] and zero-realisation for initial $\langle\mathrm{h}\rangle$ seems to have been due to the influence of French loan words, which passed on into English after the Norman Conquest (1066). Examples of words in English whose origin is French and where initial $\langle\mathrm{h}\rangle$ is found are: herb, host, honour, honest, or humour. As Lynda Mugglestone says, "French loans regularly 'dropped their [h]s', and at some date, such habits seem to have been extended into native words as well, though the exact time of this development is a matter of some dispute" (1995: 110). 
This is probably true, and it can be confirmed by simply checking the development of any of the aforementioned words in Latin, French, and English. As an example of this, we can point out the word herb, which is pronounced [h3:b] in Standard British English but [3:rb] in the United States. Originally herb comes from the Latin word herba. The pronunciation of herba according to the phonological rules of Classical Latin was /' herba/, with a clear initial aspiration. However, the weak quality of that aspiration led to the loss of that sound in later stages of Latin, and so, it became ['erba]. Then this word developed into Old French erbe, probably pronounced [erb] ${ }^{6}$ Here the $/ \mathrm{h} /$-dropping process seems to have been very advanced, as it had already taken place in the latest stages of Latin, which, in turn, are the first stages of Romance languages.

The Old French word erbe gave Modern French herbe, pronounced 3:Rb, where the $<\mathrm{h}\rangle$-spelling has been restored only for etymological but not for phonetic reasons.

The word erbe passed on into the lexis of Middle English as either erbe or herbe. Both these Middle English spellings of the Old French word erbe seem to have been pronounced [erb], as the presence of an initial $\langle\mathrm{h}\rangle$ in the second spelling of this word was only for etymological reasons.

This word became [3:rb] later on, and that is the way it has been preserved in the United States. Then, in British English, it became [h3:rb] and [hз:b], due to a spelling pronunciation. However, it is still pronounced [3:b] in those dialects of England where /h/dropping takes place, and where this /h/-dropping tendency has also been extended, as we said above, to native words like head (Old English heafod), which is then pronounced [ed] rather than $/$ hed/.

Therefore this historical development provides evidence for the impact that both Latin and Old French had on Middle English, and, subsequently, have had on Modern English, as it was only after the etymological restoration of an $\langle\mathrm{h}\rangle$ in the spelling that this word became again initially aspirated in Standard British English, remaining unaspirated in the United States and, of course, in those dialects of England where /h/-dropping is a current feature, regardless of the French or native origin of the word.

Having said that, the question now is sorting out the date when the phenomenon of the generalisation of /h/-dropping from French loan words into native English words took place.

According to J.C. Wells, "The fact that H Dropping is unknown in North America strongly suggests that it arose in England only well after the American colonies were founded. Australians, on the other hand, tend to drop /h/ just like the English, as we should expect from their settlement history" (1982: 255). Here we should add that /h/-dropping is not completely unknown in North America. However, it should also be pointed out that the only general initial /h/-dropping found in North America is that of herb in the United States, which is the exception rather than the rule. ${ }^{7}$

Other scholars, however, think that this process started around the $11^{\text {th }}$ century. Lynda Mugglestone talks about those who think this way: "Roger Lass, for example argues for a process beginning in the eleventh century" (1995: 111).

This evidence suggests that the exact moment when it took place is not easy to know. 
Yet it seems to be clear that it was known by the $18^{\text {th }}$ century, although its condemnation and its status as a shibboleth -in those English-speaking territories like England where it was a current feature- was not found until later.

According to Wells, "H Dropping has been known in popular London speech since at least the eighteenth century" (1982: 255), but, and according to Strang: "Explicit condemnation of H Dropping is first found at the close of the eighteenth century" (1970: 81). This fact is quite interesting because whenever it was that $/ \mathrm{h} /$-dropping began to take place, its condemnation did not appear immediately, but after the phenomenon had existed for some time. It seems to have been in the late $18^{\text {th }}$ century when this /h/-dropping became associated with careless speech.

The Enlightenment, the cultural movement of the $18^{\text {th }}$ century, emphasised reason against tradition. It is in this particular period of time when the first encyclopaedias were published. This fact contributed to the generalisation of an English-language written standard. Also it contributed to make people aware of how words were to be written correctly. In this context some people became aware that words where they had never used initial aspiration were spelt correctly with an initial $\langle\mathrm{h}\rangle .^{8}$ The consequence of this was that those with more access to education, that is to say, the upper class, tried to aspirate initial $\langle\mathrm{h}\rangle$ in those words which had it in their correct spelling, whereas those with less access to education, that is to say, the lower class, continued not to aspirate it.

This attitude towards language had important consequences, which were, among others, the association of this, and other dialectal features, with certain groups of people, namely the lower class, and then the stigmatisation of those particular features.

The use of /h/-dropping was quite general, regardless of social status, at that moment. As the Irish actor and theatrical manager Thomas Sheridan said, "There is one defect which more generally prevails in the counties than any other, and indeed is gaining ground among the politer part of the world, I mean the omission of the aspirate in many words by some, and in most by others" (quoted by Mugglestone 1995: 113). As we can see /h/-dropping was common even among the polite or the upper class. Now, one question arises: if it was also common among the upper class, and it was the upper class who established the rules for an English-language written standard, why was then /h/-dropping not included among the features of that standard? The answer is perhaps not easy. J.C. Wells says: "The fact that Northumbrians, Scots, Irish, Americans and Barbadians do not incline to H Dropping is sufficient proof, if proof were needed, that there is no truth in the popular English view that H Dropping is a product of laziness and original sin" (1982: 256). This popular view of $/ \mathrm{h} /$-dropping as a product of laziness could have led to the association that those who did not want to be regarded as lazy, in other words, the upper class, did emphasise the use of /h/ even though it was not a current feature among themselves either. Lynda Mugglestone says with regard to Sheridan's ideas, "the theoretically 'correct' usage of [h], in which it was pronounced rather than being dropped, was indeed rare, but it was this very rarity which was to be prized, evincing as it did the superior facilities of a small group of people able to wield the aspiration with ease, and without incurring the 'guilt' accorded to those who fail in this respect" (1995: 114). From that moment onwards the upper class did its 
best to pronounce initial $/ \mathrm{h} /$. Therefore, and as already pointed out, /h/-dropping gradually became associated with those who failed to pronounce the famous 'Poor Letter $\langle\mathrm{H}\rangle$ ', that is to say, with those who were probably not familiar with, or aware of, both the spelling conventions and the standard linguistic patterns of pronunciation. This group was of course the working and lower class and, to a certain extent, the middle class. This is crucial from the sociolinguistic point of view, because an almost general dialectal feature gets stigmatised according to that popular belief of laziness mentioned above. Therefore there is a clear link between language, social belief, and social attitudes, and, what is more, the use of aspirated $/ \mathrm{h} /$ shows the attitude of dissociation of the upper class (élite) from the rest of society. This process is very well exemplified by the attitudes of certain groups like the new rich, who, in an attempt to be as educated as the traditional upper class, incur in what is normally known as hypercorrection.

All these sociolinguistic changes have been reflected from the $18^{\text {th }}$ century onwards in the works of different writers like, for example, Charles Dickens or George Bernard Shaw. The main aim of these authors was to use certain linguistic clues to represent different social groups. The most popular representations are those of working-class Londoners (Cockneys), and those of the different attitudes of the new rich and their hypercorrect and pedantic habits.

Examples of this dialectal features in literature are very common, but we could say that there are probably three groups into which all of them could be classified. These three groups would be: first, those texts representing the attitude of dissociation found in the upper class against the lower class, then, the funny representations of the new rich and their hypercorrect habits, and, finally, the representations of the lower class which is of course characterised by initial /h/-dropping.

An interesting example of the first type appears in Dickens's Our Mutual Friend: “ 'Ah! Of a Orse?' inquired the foreign gentleman. ${ }^{9}$ / 'We call it Horse', said Mr Podsnap, with forbearance. "In England, Angleterre, England, We Aspirate the " $\mathrm{H}$ " and We Say "Horse”. Only our Lower Classes Say “Orse"!"” (in Mugglestone 1995: 116).

Another example of this is in David Herbert Lawrence's Sons and Lovers: "They're hateful, and common and hateful, they are, and I'm not going any more. Mr Braithwaite drops his 'h's', an' Mr Winterbottom says 'You was'" ${ }^{11}$ (in Blake 1981: 169).

Examples of hypercorrection can be found for example in Shaw's Captain Brassbound's Conversation: "Weoll, waw not? Waw not, gavner? Ahrs is a Free Tride nition. It grows agin us as Hinglishmen to see these bloomin furriners settin ap their Castoms Ahses and spheres o hinfluence and sick lawk hall owver Arfricar. Daownt Harfricar belong as much to huz as to them? thets wot we sy. Ennywys, there ynt naow awm in ahr business. All we daz is hescort, tourist, hor commercial. Cook's hexcursions to the Hatlas Mahntns: thets hall it is. Waw, its spreadin civlawzytion, it is. Ynt it nah?"12 (in Wells 1982: 334).

Finally, cases of simple /h/-dropping are found in lots of different literary sources. As an example of this we can point out some passages of Shaw's Major Barbara as the one that follows: 
BILL. Youre Todger Firemawl, are you?

TODGER. Sergeant Fairmile, at your service, sir.

BILL. You took awy maw judy, did you? Nime of Mog Ebbijam.

MOG. Bill!! Dont you know me?

BILL. Blaow me! Its $e r$ voice. Wot $e v$ you dan t'yseeawf? Wotz $e$ dan to you?

MOG. Sergeant: it's Bill Walker, that was my bloke. And I'm so changed he doesnt know me.

TODGER. We'll make the same change in you, Bill. Is that what youve come for?

BILL. Awv cam to ev me fice chynged rawt enaff; an' youre the menn that's gaoin to chynge it. Tike thet. [He spits in Todger's face.] Nah, eah's maw jawr. Itt it. Itt it your best. Brike it. ${ }^{13}$ (in Blake 1981: 165)

Or some passages of Rudyard Kipling's Mandalay: "But that's all shove be'ind me -long ago an' fur away, / An' there ain't no 'busses running' from the Bank to Mandalay; / An' I'm learnin' 'ere in London what the ten-year soldier tells: / 'If you've 'eard the East acallin', you won't never 'eed naught else.' / No! you won't 'eed nothin' else / But them spicy garlic smells, / An' the sunshine an' the palm-trees an' the tinkly / temple-bells; / On the road to Mandalay..." (in Blake 1981: 165).

These texts make clear the repercussions of /h/-dropping not only in the context of society, but also in the context of literary conventions, which made use of certain linguistic patterns in an attempt to represent the different social characters and strata.

Finally, and as a conclusion, we should say that social ideas associated with linguistic features have led to symbols of the Social Divide. This is what happened to /h/-dropping, a mere historical phonetic development which became highly stigmatised and related to the lower levels of society, due to an association of ideas in $18^{\text {th }}$-century England, and which is still one of the most powerful shibboleths of class in the context of early $21^{\text {st }}$-century British English.

\section{Notes}

1. Cases of $/ \mathrm{h} /$-dropping can be also found in words like behind, ahead, rehearse, or Wolverhampton where the $<\mathrm{h}>$ is not in initial but in medial position. Nonetheless, even in cases like these, the $<\mathrm{h}>$ is still syllable-initial.

2. An alternative way to represent the $/ \mathrm{hw} /$-group is the use of the symbol $/ \mathrm{M} /$.

3. The allophone [h] was normally syllable-initial as in him "him".

4. See footnote number 1.

5. From this point onwards we will refer to non-standard initial /h/-dropping as simply /h/dropping.

6. Hypothesis derived upon the basis of the pronunciation of the word herba in the latest stages of Latin and the pronunciation of the development of the word erbe into Modern French.

7. In the United States we also find initial /h/-dropping in cases like that of the word humble; however, these cases are not general and are only restricted to the dialects of the South East.

8. See footnote number 1 . 
9. He was French.

10. Italics: Examples of / $\mathrm{h} /$-dropping. Note the fact that the first case is an influence of French phonetics, while the second is an example of England's lower-class speech.

11. Single quotation marks in 'h's' and 'You was' appear as double marks in the source from which this text has been quoted. However, they have been changed as here they are cases of quotations within a quotation.

12. Italics: Examples of hypercorrection. Note the interesting use of the word Africa which appears both as Arfricar and as Harfricar, where we find hypercorrection again, but this time also associated with another dialectal feature: rhoticity.

It is also very interesting to check the rest of Cockney features present in this text, like the historical confusion of $/ \mathrm{v} /$ and $/ \mathrm{w} /$ in London English, although this feature seems to have died out during the $20^{\text {th }}$ century and is no longer found in everyday Cockney speech.

Another feature typical of the South East of England which is also present here is that of the pronunciation of the standard diphthong /eI/ as [ar]. This characteristic is shown in this text by an $<\mathrm{i}>$ or a $<\mathrm{y}>$ in the spelling of words like nition "nation" or sy "say".

13. Italics: /h/-dropping, except in the case of the sentence in square brackets which is a stage direction.

14. Italics: /h/-dropping.

\section{Endnotes}

i. Italics: / $\mathrm{hw} /$-pronunciation.

Length-marks and the distinction of $\langle\dot{\mathrm{c}}\rangle$ and $\langle\dot{\mathrm{g}}\rangle$ from $\langle\mathrm{c}\rangle$ and $\langle\mathrm{g}\rangle$ have been omitted here as those spelling conventions were not used in Old English.

\section{Translation:}

What craft do you know? / I am a fisherman. / What do you get from your craft? / I get food for me, and clothing, and money. / How do you catch fish? / I go on my boat, and I row out on the river, and I throw my net on the river. Sometimes I throw out a hook with a bait, or baskets; and I take whatever they catch. / What do you do if the fish are not clean? / I throw the unclean ones out, and take the clean ones as food for me. / Where do you sell your fish? / In town. / Who buys them? / The city-dwellers. I cannot catch as many of them as I would be able to sell. / What kind of fish do you catch? / Eels, and pike, and trout, and all the other fish that are swimming in the rivers. / Why do not you go fishing on the sea? / Sometimes I do so, but rarely; because I am quite afraid of the sea. / What do you catch on the sea? / Herrings, and salmon, and sturgeons, and lobsters, and crabs, and many other fish.

My own translation. 


\section{References}

Allen, William Sydney (1978 [1965]): Vox Latina: A Guide to the Pronunciation of Classical Latin. $2^{\text {nd }}$ ed. Cambridge and New York: Cambridge University Press.

Blake, Norman Francis (1981): Non-Standard Language in English Literature. London: Deutsch.

Brook, George Leslie (1957): English Sound Changes. Manchester: Manchester University Press. . (1970): The Language of Dickens. London: Deutsch.

Corréard, Marie-Hélène and Valerie Grundy (eds.)(1997 [1994]): The Oxford-Hachette French Dictionary: French-English, English-French. $2^{\text {nd }}$ ed. Oxford and New York: Oxford University Press.

Dobson, Eric John (1968 [1957]): English Pronunciation 1500-1700. 2 vols. $2^{\text {nd }}$ ed. Oxford: Clarendon.

Hughes, Arthur and Peter Trudgill (1996 [1979]): English Accents and Dialects: an Introduction to Social and Regional Varieties of British English. $3^{\text {rd }}$ ed. London: Edward Arnold.

Mitchell, Bruce and Fred C. Robinson (1992 [1964]): A Guide to Old English. $5^{\text {th }}$ ed. Oxford and Malden, Massachusetts: Blackwell.

Mugglestone, Lynda (1995): Talking Proper: the Rise of Accent as Social Symbol. Oxford: Clarendon.

Onims, Char les Talbut (ed.)(1966): The Oxford Dictionary of English Etymology. Oxford and New York: Oxford University Press.

Pearsall, Judy and Bill Trumble (eds.)(1996 [1995]): The Oxford English Reference Dictionary. $2^{\text {nd }}$ ed. Oxford and New York: Oxford University Press.

Scholze-Stubenrecht, Werner and J. B. Sykes (eds.)(1990): The Oxford-Duden German Dictionary: German-English, English-German. Oxford: Clarendon.

Strang, Barbara Mary Hope (1970): A History of English. London: Methuen.

Sweet, Henry (1882): An Anglo-Saxon Primer. Ed. Norman Davis (1953): Sweet's Anglo-Saxon Primer. $9^{\text {th }}$ ed. Oxford: Oxford University Press.

Tulloch, Sarah (ed.)(1995): The Oxford Dictionary and Thesaurus. Oxford: Oxford University Press.

The Oxford English Dictionary. (1989 [1933]): $2^{\text {nd }}$ edition. Oxford: Clarendon.

Wells, John Christopher (1982): Accents of English. 3 vols. Cambridge: Cambridge University Press. 